\title{
Association of PDGFRA gene polymorphisms and early-onset myopia in South Sumatera, Indonesia
}

\author{
Mitayani Purwoko ${ }^{1,2}$, Winarto Reki ${ }^{3,4}$, Tri Indah Winarni ${ }^{5}$ \\ 'Postgraduate Programme of Biomedical Science, Concentration in Genetic \\ Counseling, Faculty of Medicine Diponegoro University, Semarang, Indonesia; \\ ${ }^{2}$ Faculty of Medicine, Muhammadiyah University, Palembang, Indonesia; \\ ${ }^{3}$ Department of Ophthalmology, Faculty of Medicine Diponegoro University, \\ Semarang, Indonesia; ${ }^{4}$ Department of Clinical Microbiology, Faculty of Medicine \\ Diponegoro University, Semarang, Indonesia; ${ }^{5}$ Center for Biomedical Research \\ (CEBIOR), Faculty of Medicine Diponegoro University, Semarang, Indonesia
}

\begin{abstract}
Purpose: Myopia is a refraction error that may be caused by corneal curvature (CC) anomaly. The platelet-derived growth factor receptor alpha (PDGFRA) gene was determined to have an effect on the CC. The purpose of this study was to find a correlation between single nucleotide polymorphisms (SNP) in the PDGFRA gene and early-onset myopia in people of South-Sumatera origin, a part of an Indonesian ethnic group.

Design: Using a random sampling method, this population-based, case-control study included 100 subjects aged 18-40 years from Palembang, South Sumatera, Indonesia.

Methods: Visual acuity was measured by Snellen chart and the CC was measured by manual keratometer. DNA sample from buccal swab was investigated with Amplification Refractory Mutation System (ARMS) polymerase chain reaction (PCR) and visualized in agarose gel.

Results: Median of CC for the right eye was 7.73 (7.07-8.63) $\mathrm{mm}$ and the left eye was 7.73 (7.04-8.69) $\mathrm{mm}$. There was no difference between CC in myopic and normal subjects. Distribution of mutant allele in rs 17084051, rs7677751, rs7682912, and rs2114039 were higher in myopic subject compare to those of normal control. Significant association between PDGFRA gene polymorphism and early-onset myopia was found only in rs17084051 ( $p=$ $0.009)$ and $r s 7677751(p=0.001)$.

Conclusions: Mutant type allele A of rs 17084051 and mutant type allele T of rs 7677751 of PDGFRA gene polymorphism are associated with early-onset myopia in South-Sumatera tribes in this study.
\end{abstract}

Keywords: corneal curvature, early-onset myopia, Indonesia, myopia, polymorphism, PDGFRA, SNP

\section{Introduction}

The eye is the most important human sensory organ that plays a critical role in human-environmental interaction. In 1996 and 1997, the WHO Program and the Task Force to the Partnership Committee of collaborating Non-Governmental Organizations launched The Global Initiative for the Elimination of Avoidable Blindness. The mission of this program is to have eliminated the main cause of all preventable and

Correspondence: Mitayani Purwoko, Faculty of Medicine Muhammadiyah University Palembang Jalan K.H. Balqhi, 13 Ulu, Palembang 30263, Indonesia

E-mail: mitayani.dr@gmail.com 
treatable blindness by the year 2020. Refractive error is the most common diseasecausing visual impairment, especially myopia (or nearsightedness). ${ }^{1}$

The highest rate of myopia occurs in Bali, among the age group 11-20 years old $(25.1 \%)$. $^{2}$ Some factors may play a role in myopia, such as corneal curvature (CC), lens thickness, and axial length of the eye. ${ }^{3-5}$ The cornea in the myopic eye tends to be steeper compared to the normal eye. ${ }^{6}$ The CC tends to be flatter in infancy and then stabilize from one year old until 18 years old. ${ }^{7}$

Myopia is a complex disease that may be caused by a genetic factor or environmental factors. ${ }^{3,4,8}$ If a genetic factor was involved, myopia can be also inherited through Mendelian trait, i.e., autosomal dominant, autosomal recessive, and X-linked. ${ }^{3,4}$ Based on the onset, myopia can be divided into three groups: earlyonset ( $<20$ years old), early-adult onset (20-40 years old), and late-adult onset ( $>$ 40 years old). So, early-onset myopia is nearsightedness that happens before the age of $20,3,5$

There are some studies dedicated to find the genetic role in myopia. PAX6 were determined to play a role in high myopia in Han Chinese ${ }^{9}$ and Japanese populations. ${ }^{10}$ P4HA2 was associated with non-syndromic high myopia. ${ }^{11}$ High myopia was found associated with homozygous frameshift mutation in LRPAP1 gene. ${ }^{12}$ The GJD2, RASGRF1, BICC1, KCNQ5, CD55, CYP26A1, LRRC4C, and B4GALNT2 were associated with myopia in the Japanese population. ${ }^{13} \mathrm{~A}$ study by Han et al. found polymorphisms in FRAP1 and PDGFRA gene which were associated with CC in three ethnic groups in Singapore (Chinese, Malay, and India). ${ }^{14}$ Mishra et al. and Guggenheim et al. replicated the study with different populations and found a correlation between PDGFRA gene and CC.,15

PDGFRA gene located at chromosome $4 \mathrm{q} 12$ encoded a protein called plateletderived growth factor receptor alpha. This receptor has an intracellular tyrosine kinase activity. When activated, the receptor will start a signaling process through MAP kinase, PI3 kinase, and C-gamma protein kinase. Epithelial and corneal stromal tissue are sensitive to the growth mediator which is activated by MAP and PI3 kinase. ${ }^{16}$ PDGFRA were expressed in corneal tissue, especially in epithelial cells, stromal fibroblast, and endothelial cells. ${ }^{17}$ Guggenheim et al. performed antibody labeling in cornea models and found that the most PDGFRA protein expressions were in cornea epithelial and stromal tissue. ${ }^{7}$

The purpose of this study was to find a correlation between SNPs in the PDGFRA gene and early-onset myopia in people of South-Sumatera origin.

\section{Methods}

Using a random sampling method, this population-based, cross-sectional study included 100 subjects aged 18-40 years from Palembang, South Sumatera, Indonesia. Myopic subjects were selected from the academic community of Faculty of Medicine Muhammadiyah University Palembang, South Sumatera, Indonesia. The selection was based on a visual acuity test in both eyes, using a Snellen chart. Inclusion criteria for the case group were male or female of South-Sumatera origin with a visual acuity of $<6 / 6$ (in meters) in both eyes, a positive response with 
spherical concave lens, age at examination 18-40 years, and literacy.

Because people of South-Sumatera origin with normal eyes were limited in the academic community of the Faculty of Medicine Muhammadiyah University of Palembang, the control subjects were selected from a community outside the case population. Inclusion criteria for the control group were male or female of SouthSumatera origin with visual acuity $6 / 6$ (in meters), negative response with spherical concave and convex lens in both eyes, age at examination 18-40 years, and literacy. Exclusion criteria for both groups were subject with early-adult and late-adult onset of myopia, hyperopia, myopia only in one eye, a history of ophthalmic surgery, and ophthalmic disease during examination.

The history of the selected subjects was taken and keratometry with manual keratometer (Takagi, Japan) was performed. This study followed the tenets of the Declaration of Helsinki. Informed consent was obtained from each subject after the explanation of the nature and possible consequences of the study. This study was approved by the Committee of Bioethics, Humanities, and Islamic Medicine of Faculty of Medicine Muhammadiyah University Palembang.

DNA was extracted from a buccal swab using a Genenaid Presto ${ }^{\mathrm{TM}}$ Buccal Swab DNA extraction kit following the manual instructions. DNA quantification was performed using Nanovue Plus. This study investigated seven SNPs: rs7676985, rs17084051, rs7677751, rs2307049, rs7682912, rs7660560, and rs2114039 in the PDGFRA gene. Molecular investigation was done using Amplification Refractory Mutation System PCR (ARMS PCR). Primers for ARMS PCR were designed by http:// www.primer1.soton.ac.uk/primer1.html.

The PCR reagents mixture consisted of $5 \mu$ KAPA SYBR Fast Universal qPCR kit, 1 $\mu \mathrm{l}$ for each $5 \mathrm{pmol} / \mu \mathrm{l}$ primer, $1 \mu \mathrm{l}$ DNA sample $10 \mu \mathrm{g} / \mu \mathrm{l}$, and $1 \mu \mathrm{l} \mathrm{H} 2 \mathrm{O}$ PCR grade. $\mathrm{PCR}$ reaction for rs 17084051 was hold $195^{\circ} \mathrm{C} 3^{\prime}, 40$ times $\left(95^{\circ} \mathrm{C} 10^{\prime \prime}, 60^{\circ} \mathrm{C} 30^{\prime \prime}, 72^{\circ} \mathrm{C}\right.$ $\left.30^{\prime \prime}\right)$, and hold $272^{\circ} \mathrm{C} 2^{\prime}$. PCR reaction for rs 7677751 was hold $195^{\circ} \mathrm{C} 3^{\prime}, 40$ times $\left(95^{\circ} \mathrm{C} 10^{\prime \prime}, 55^{\circ} \mathrm{C} 30^{\prime \prime}, 72^{\circ} \mathrm{C} 30^{\prime \prime}\right)$, and hold $272^{\circ} \mathrm{C} 2^{\prime}$.

\section{Results}

This study recruited 100 South-Sumatera people, 50 people were myopic and 50 people were control; 67 (67\%) were female and 33 (33\%) were male (Table 1). 
Table 1. Distribution of sex, visual acuity, and corneal curvature.

\begin{tabular}{|c|c|c|c|c|c|}
\hline Classification & Case Group & Control Group & & & \\
\hline & Frequency & $\begin{array}{c}\text { Percentage } \\
\text { (\%) }\end{array}$ & Frequency & $\begin{array}{c}\text { Percentage } \\
\text { (\%) }\end{array}$ & \\
\hline \multicolumn{6}{|l|}{ Sex } \\
\hline Male & 41 persons & 82 & 26 persons & 52 & \\
\hline Female & 9 persons & 18 & 24 persons & 48 & \\
\hline Total & 50 persons & 100 & 50 persons & 100 & \\
\hline \multicolumn{6}{|l|}{ Visual acuity } \\
\hline$<6 / 6$ & 100 eyes & 100 & 0 eyes & 0 & \\
\hline $6 / 6$ & 0 eyes & 0 & 100 eyes & 100 & \\
\hline Total & 100 eyes & 100 & 100 eyes & 100 & \\
\hline \multicolumn{6}{|l|}{ Myopia } \\
\hline < 3 Dioptri & 81 eyes & 81 & & & \\
\hline 3-6 Dioptri & 13 eyes & 13 & & & \\
\hline > 6 Dioptri & 6 eyes & 6 & & & \\
\hline Total & 100 eyes & 100 & & & \\
\hline \multicolumn{6}{|l|}{ Corneal curvature } \\
\hline \multirow[t]{2}{*}{ Right eye } & $\leq 7.8 \mathrm{~mm}$ & 35 eyes & 35 & 29 eyes & 29 \\
\hline & $>7.8 \mathrm{~mm}$ & 15 eyes & 15 & 21 eyes & 21 \\
\hline \multirow[t]{2}{*}{ Left Eye } & $\leq 7.8 \mathrm{~mm}$ & 34 eyes & 34 & 30 eyes & 30 \\
\hline & $>7.8 \mathrm{~mm}$ & 16 eyes & 16 & 20 eyes & 20 \\
\hline Total & 100 eyes & 100 & 100 eyes & 100 & \\
\hline
\end{tabular}

Median of the CC (interquartile range) for the right eye was 7.72 (7.60-7.93) $\mathrm{mm}$ and for the left eye 7.73 (7.59-7.91) $\mathrm{mm}$. The mean value of the $C C$ radius in this study for the right eye was $7.75 \pm 0.24 \mathrm{~mm}$ and for the left eye $7.76 \pm 0.25 \mathrm{~mm}$.

We distinguished different genotypes of subjects using ARMS PCR. The accuracy of this method was confirmed by sequencing of positive control samples (Figs. 1 and 2). 

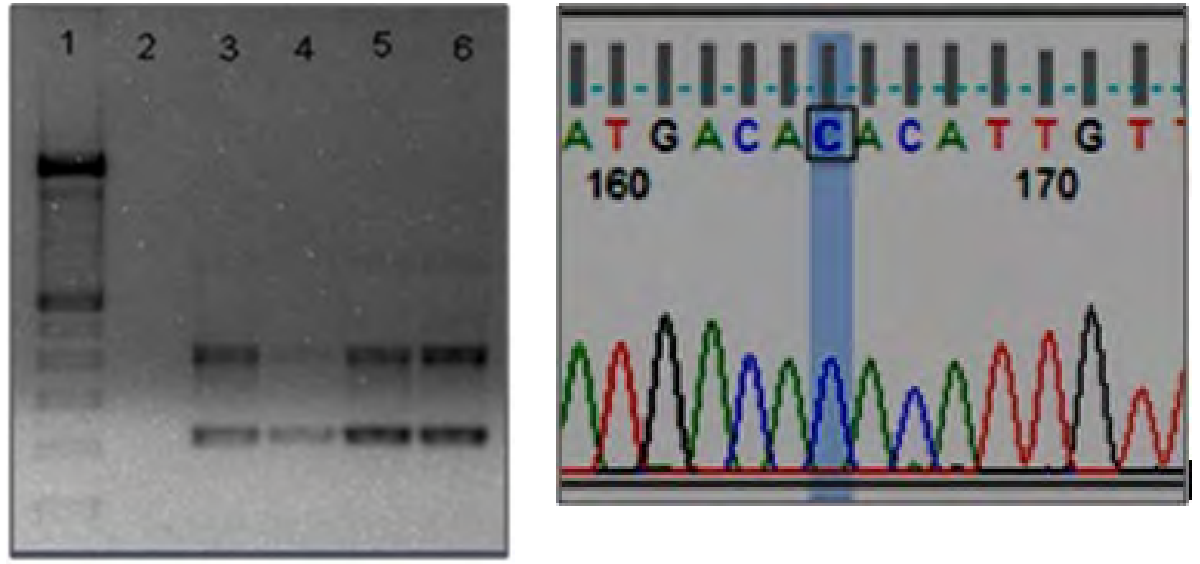

Fig. 1. Electrophoresis result of rs7677751 ARMS PCR for wild type allele. Left: Wild type allele $C$ shown as control band at $409 \mathrm{bp}$ and inner band at $212 \mathrm{bp}$. (Lane 1: Marker ladder 100bp, 2: Blank, 3: Positive control, 4-6: Wild type allele positive). Right: Positive control showed allele $\mathrm{C}$ in the sequencing result.
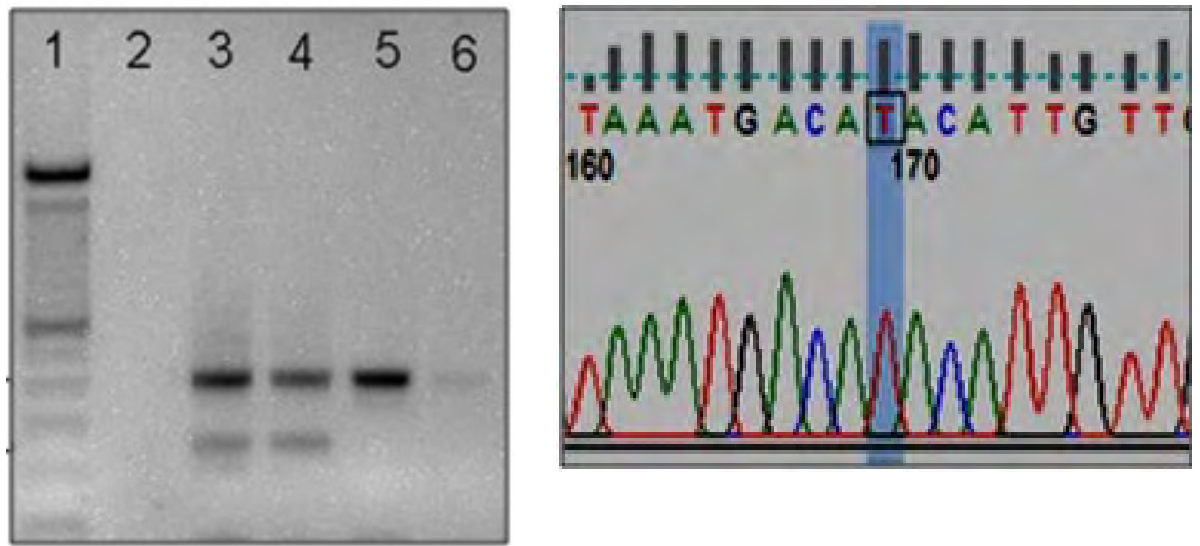

Fig. 2. Electrophoresis result of rs7677751 ARMS PCR for mutant type allele. Left: Mutant allele T shown as control band at 409 bp and inner band at 250 bp. (Lane 1: Marker ladder 100bp, 2: Blank, 3: Positive Control, 4: Mutant allele positive, 5-6: Mutant allele negative). Right: Positive control showed allele $\mathrm{T}$ in the sequencing result.

A significant $p$ value of $<0.05$ was found in two SNPs: rs 17084051 and rs7677751. Those two SNPs had a positive association with early-onset myopia. There was no correlation between the seven SNPs with CC in the people of South-Sumatera origin ( $p>0.05$ for both eyes). 
Table 2. Association between mutant allele of SNPs and early-onset myopia.

\begin{tabular}{|c|c|c|c|c|c|c|c|}
\hline SNP & $\begin{array}{c}\text { Mutant } \\
\text { Allele }\end{array}$ & $\begin{array}{c}\text { MAF in } \\
\text { South } \\
\text { Sumatera } \\
\text { population }\end{array}$ & $\begin{array}{c}p \text { value for } \\
\text { early-onset } \\
\text { myopia }\end{array}$ & PR & Cl 95\% & \multicolumn{2}{|c|}{$p$ value for CC } \\
\hline & & & & & & & \\
Right & $\begin{array}{c}\text { Left } \\
\text { eye }\end{array}$ \\
\hline rs7676985 & A & 0.18 & 0.137 & 0.53 & $0.23-1.23$ & 0.958 & 0.958 \\
\hline rs17084051 & A & 0.29 & 0.009 & 2.94 & $1.30-6.65$ & 0.738 & 0.738 \\
\hline rs7677751 & T & 0.24 & 0.001 & 4.15 & $1.80-9.57$ & 0.423 & 0.701 \\
\hline rs2307049 & A & 0.43 & 0.130 & 0.52 & $0.22-1.22$ & 0.331 & 0.331 \\
\hline rs7682912 & G & 0.45 & 0.159 & 1.77 & $0.80-3.92$ & 0.933 & 0.933 \\
\hline rs7660560 & A & 0.20 & 0.838 & 1.09 & $0.49-2.43$ & 0.384 & 0.657 \\
\hline rs2114039 & C & 0.32 & 0.161 & 1.76 & $0.80-3.89$ & 0.423 & 0.701 \\
\hline
\end{tabular}

$\mathrm{MAF}=$ Minor allele frequency; $\mathrm{PR}=$ prevalence risk; $\mathrm{Cl}=$ confidence interval; $\mathrm{CC}=$ corneal curvature.

Minor allele frequency (MAF) of seven SNPs from all South-Sumatera subjects were resumed and compared to Malay Singaporean subjects from previous study (Table 2). ${ }^{9}$ There were four SNPs in the South-Sumatera tribe that have high MAF compared to the Malay Singaporean population.

\section{Discussion}

The mean value of the $\mathrm{CC}$ radius in this study was higher than the mean value of the CC in three major ethnic groups in Singapore based on a previous study. In the Malay Singaporean population, the mean value was $7.66 \mathrm{~mm}$, in the Indian Singaporean population $7.62 \mathrm{~mm}$, and in the Chinese Singaporean population 7.73 $\mathrm{mm} .^{14}$

Some studies found an association between the $\mathrm{CC}$ and refractive anomaly. The myopic eye has a steeper CC than the normal eye. ${ }^{6,7,18}$ Carney et al. (1997) found a difference between the mean value of the CC in emmetropic people and high myopic people. ${ }^{6}$ Saw et al. (2002) in their study found the mean value of the CC in higher myopia was $7.67 \mathrm{~mm}$ and in lower myopia $7.71 \mathrm{~mm}$. They also found a $p$ value of 0.001 for the CC in higher myopia. ${ }^{19}$ The CC in higher myopia and lower myopia was classified as steeper cornea $(\leq 7.8 \mathrm{~mm})$. This study found no correlation between CC and early-onset myopia ( $p$ value $>0.05$ ). When we tried to classify myopia into high myopia ( $6 \mathrm{D}$ ) and low myopia $(\leq 6 \mathrm{D})$, we found no difference between the CC in high myopia and low myopia ( $p$ value $>0.05$ ). Perhaps that is why in this study we could not find a correlation between the CC and SNPs in the PDGFRA gene.

A study in Taiwan, Australia, and China also found that males had a higher CC radius 
compared to females..$^{20,21,22}$ The CC radius of males of South Sumatera origin was higher (right eye mean $7.79 \pm 0.23 \mathrm{~mm}$, left eye mean $7.83 \pm 0.26 \mathrm{~mm}$ ) compared to the CC of females (both eyes mean $7.72 \pm 0.23 \mathrm{~mm}$ ). However, in Nigerians, females had a higher $\mathrm{CC}$ radius. ${ }^{23}$ Although the male $\mathrm{CC}$ was higher than the female $\mathrm{CC}$, this study found no differences in statistics between male and female CC ( $p>0.05)$, just like a study in Taiwan school children that found no difference in CC radius between boys and girls. ${ }^{22}$

There were no SNPs of the PDGFRA gene that had an association with the CC in people of South Sumatera origin in this study. However, this study found a positive association between mutant allele in rs 17084051 and mutant allele in rs7677751 with early-onset myopia. People with positive mutant allele in rs17084051 and rs7677751 was having 2.94 and 4.15 greater risk, respectively, for having earlyonset myopia. Because those both SNPs were not associated with CC, perhaps they were affecting another path of myopia pathophysiology, such as axial length or lens thickness. Based on the Ocular Tissue Database, the lens had the highest expression of PDGFRA protein with 745.489 PLIER while the cornea only had 88.85 PLIER. ${ }^{24}$ PDGFRA protein also expressed in lens epithelium and conducted of hyperproliferation and ectopic differentiation into lens fiber cells. ${ }^{25}$ rs 7677751 was found to be associated with corneal astigmatism in the Singapore population, ${ }^{26}$ but not in the Australian population. ${ }^{27}$

SNP rs17084051, rs2307049, rs7682912, and rs2114039 were having MAF 0.29, $0.43,0.45$, and 0.32 respectively. These MAFs were higher than MAF in the Malay Singaporean population. This condition described that the mutant allele $A$ in these SNPs was more existing in the South Sumatera population, Indonesia. The difference in MAF in those SNPs between these two populations may be caused by different ethnicity.

As a multifactorial disease, myopia could be caused by a genetic factor and/or an environmental factor. There was lack of information about genetic involvement in myopia development in Indonesian population. The limitations of this study were the small sample size and the fact that this study only focused on the genetic factor, comparing the genetic susceptibility between people of South Sumatera origin and other ethnicities. For further studies, the environmental factor can be investigated together with the genetic factor so we can resumed which factor that play the biggest role in early onset myopia among South Sumatera tribe population in a bigger sample size.

\section{Conclusion}

Mutant type allele A of rs 17084051 and mutant type allele T of rs7677751 PDGFRA gene polymorphism are associated with early-onset myopia in people of South Sumatera origin, Indonesia. 


\section{Acknowledgements}

We thank the dean and staff members of the Faculty of Medicine Muhammadiyah University Palembang for the permission of sampling; the director and staff members of the CEBIOR Faculty of Medicine Diponegoro University for their permission in laboratory investigation; Hasmeinah, Indri Ramayanti and Dini Arraya Putri for helping in sampling processes; and the Research and Development Center of the Indonesian Ministry of Health for the research grant in 2014 (LB0201/I.1/363/2014).

\section{References}

1. Thylefors B. A global initiative for the elimination of avoidable blindness [editorial]. Am J Ophthalmol 1998;125(1):90-93. http://www.ncbi.nlm.nih.gov/pmc/articles/PMC1706044

2. Handayani-Ariestanti T, Supradnya-Anom IGN, Pemayun-Dewayani Cl. Characteristic of patients with refractive disorder at eye clinic of Sanglah General Hospital Denpasar, Bali, Indonesia, Period of $1^{\text {st }}$ January-31 ${ }^{\text {st }}$ December 2011. Bali Medical Journal 2012;1:3:101-107. http://www. balimedicaljournal.org/index.php/bmj/article/view/23

3. Metlapally R, Ki CS, Li YJ, et al. Genetic association of Insulin-like Growth Factor-1 Polymorphisms with High-grade Myopia in an International Family Cohort. Invest Ophthalmol Vis Sci 2010;51(9):4476-4479. doi: 10.1167/iovs.09-4912.

4. Tang WC, Yap MKH, Yip SP. A review of current approaches to identifying human genes involved in myopia. Clin Exp Optom 2008;91(1):4-22. http://www.ncbi.nlm.nih.gov/pubmed/18045248

5. Zejmo M, Forminska-Kapuscik M, Pieczara E, et al. Etiopathogenesis and management of high-degree myopia. Part I. Med Sci Monit 2009;15(9):RA199-202. http://www.ncbi.nlm.nih.gov/ pubmed/19721411

6. Carney LG, Mainstone JC, Henderson BA. Corneal Topography and myopia: A Cross sectional study. Invest Ophthalmol Vis Sci 1997;38(2):311-320. http://www.ncbi.nlm.nih.gov/pubmed/9040463

7. Guggenheim JA, McMahon G, Kemp JP, et al. A genome-wide association study for corneal curvature identifies the platelet-derived growth factor receptor alpha genes as a quantitative trait locus for eye size in white Europeans. Mol Vis 2013;19:243-253. http://www.ncbi.nlm.nih.gov/ pubmed/23401653

8. Read SA, Collins MJ, Carney LG. A review of astigmatism and its possible genesis. Clin Exp Optom 2007; 90(1):5-19. http://www.ncbi.nlm.nih.gov/pubmed/17177660

9. Jiang B, Yap MK, Leung KH, et al. PAX6 haplotypes are associated with high myopia in Han Chinese. PloS One 2011;6(5):e19587. doi: 10.1371/journal.pone.0019587.

10. Miyake M, Yamashiro K, Nakanishi H, et al. Association of paired box 6 with high myopia in Japanese. Mol Vis 2012;18:2726-2735. http://www.ncbi.nlm.nih.gov/pubmed/23213273

11. Guo H, Tong P, Liu Y, et al. Mutations of P4HA2 encoding prolyl 4-hydroxylase 2 are associated with nonsyndromic high myopia. Genet Med 2015;17(4):300-306. doi: 10.1038/gim.2015.28.

12. Jiang D, Li J, Xiao X, et al. Detection of Mutations in LRPAP1, CTSH, LEPREL1, ZNF644, SLC39A5, and SCO2 in 298 families with early-onset high myopia by exome sequencing. Invest Ophthalmol Vis Sci 2015;56(1):339-345. doi: 10.1167/iovs.14-14850.

13. Yoshikawa M, Yamashiro K, Miyake M, et al. Comprehensive replication of the relationship between myopia-related genes and refractive errors in a large Japanese cohort. Invest Ophthalmol Vis Sci 2014;55(11):7343-7354. doi: 10.1167/iovs.14-15105.

14. Han $S$, Chen $P$, Fan $Q$, et al. Association of variants in FRAP1 and PDGFRA with corneal curvature in Asian populations from Singapore. Hum Mol Genet 2011;20(18):3693-3698. doi: 10.1093/hmg/ ddr269.

15. Mishra A, Yazar S, Hewitt AW, et al. Genetic variants near PDGFRA are associated with corneal curvature in Australians. Invest Ophthalmol Vis Sci 2012;53(11):7131-7136. doi: 10.1167/ iovs.12-10489.

16. Fan DS, Lam DS, Lam RF, et al. Prevalence, Incidence, and Progression of Myopia of School Children in Hong Kong. Invest Ophthalmol Vis Sci 2004;45(4):1071-1075. http://www.ncbi.nlm.nih.gov/ pubmed/15037570 
17. Hoppenreijs VP, Pels E, Vrensen GF, Felten PC, Treffers WF. Platelet-Derived Growth Factor: Receptor Expression in Corneas and Effect on Corneal Cells. Invest Ophthalmol Vis Sci 1993;34(3):637-649. http://www.ncbi.nlm.nih.gov/pubmed/8449682

18. Xu L, Wang YX, Guo Y, You QS, Jonas JB; the Beijing Eye Study Group. Prevalence and Associations of Steep Cornea/Keratoconus in Greater Beijing. The Beijing Eye Study. PLos ONE 2012;7(7):e39313. doi:10.1371/journal.pone.0039313

19. Saw SM, Chua WH, Hong CY, et al. Nearwork in Early-onset Myopia. Invest Ophthalmol Vis Sci 2002; 43:2: 332-339. http://www.ncbi.nlm.nih.gov/pubmed/11818374

20. Zhang YY, Jiang WJ, Teng ZE, et al. Corneal curvature radius and associated factors in Chinese children: The Shandong Children Eye Study. PLOS ONE 2015;10(2): e0117481. doi: 10.1371/journal. pone.0117481.

21. Atchison DA, Markwell EL, Kasthurirangan S, Pope JM, Smith G, Swann PG. Age-Related Changes in Optical and Biometric Characteristics of Emmetropic Eyes. J Vis 2008;8(4):29:1-20. doi: 10.1167/8.4.29.

22. Lin LL, Shih YF, Hsiao CK, Chen CJ, Lee LA, Hung PT.vEpidemiologic study of the prevalence and severity of myopia among school children in Taiwan in 2000. J Formos Med Assoc 2001;100(10):684-691. http://www.ncbi.nlm.nih.gov/pubmed/11760374

23. Iyamu E, Osuobeni E. Age, gender, corneal diameter, corneal curvature and central corneal thickness in Nigerians with normal intra ocular pressure. J Optom 2012;5:87-97. doi: 10.1016/j. optom.2012.02.001

24. Ocular Tissue Database. Cited on $14^{\text {th }}$ June, 2015. Available from: https://genome.uiowa.edu/otdb/ search?term=pdgfra\&type=symbol\&level=core

25. Andrae J, Gallini R, Betsholtz C. Role of Platelet-Derived Growth Factors in Physiology and Medicine. Genes Dev 2008;22(10):1276-1312. doi: 10.1101/gad.1653708.

26. Fan Q, Zhou X, Khor CC, et al. Genome-Wide Meta-Analysis of Five Asian Cohorts Identifies PDGFRA as a Susceptibility Locus for Corneal Astigmatism. PLoS Genet 2011:7(12):e1002402. doi:10.1371/ journal.pgen.1002402

27. Yazar S, Mishra A, Ang W, et al. Interrogation of the platelet-derived growth factor receptor alpha locus and corneal astigmatism in Australians of Northern European ancestry: Results of a genome-wide association study. Mol Vis 2013;19:1238-1246. http://www.ncbi.nlm.nih.gov/ pubmed/23761726 